\title{
Genus Alga pada Lahan Sawah Organik yang Ditanami Padi Lokal dan Inhibrida di Subak Jatiluwih, Tabanan
}

\author{
SAWIDYA FITRIYANI*), I WAYAN DANA ATMAJA, DAN NI NENGAH SONIARI
}

Program Studi Agroekoteknologi, Fakultas Pertanian Universitas Udayana

${ }^{*}$ E-mail: sawidyafitriyani2@gmail.com

\begin{abstract}
Algae Genus in Organic Rice Fields Planted with Local and Inhibrida Rice in Subak Jatiluwih, Tabanan. The abundance of microalgae in rice fields, especially microalgae from Cyanophyta division that are capable of fixing nitrogen, is very important helping maintain soil fertility. The aim of this study was to find out the genus of algae in organic rice fields of Subak Jatiluwih, Tabanan. The research was conducted from September 2018 to April 2019. Sampling was done in Subak Jatiluwih. Algae breeding were carried out at Biology and Physics Laboratory, Faculty of Agriculture, Udayana University. This research method uses descriptive quantitative. The implementation of the research included the determination of location, soil and water sampling, identification of algae, and analysis of algae genera. Enrichment algae was carried out using the MPN method, results of the analysis of algae genus were found in 37 genera from 3 divisions i.e Chlorophyta, Cyanophyta and Chrysophyta. Descriptive quantitative method Most Probable Number (MPN) calculation conclude that there are not much different from the Local and Inhibrida rice fields. The maximum population algae of local rice fields is 1.100 cell $\mathrm{g}^{-1}$ and Inhibrida rice fields is $>1.100$ cell $\mathrm{g}^{-1}$ of land. The minimum population is 3,6 cell g $^{-1}$ of land in local rice fields, and 9,2 cell $\mathrm{g}^{-1}$ of land in Inhibrida rice fields.
\end{abstract}

Keywords: Inhibrida rice field, Local rice field, Microalgae, Organic rice field, Subak Jatiluwih

\section{PENDAHULUAN}

Sistem pertanian yang dijalankan oleh masyarakat Desa Jatiluwih, Kecamatan Penebel, Kabupaten Tabanan, Bali adalah sistem pertanian organik. Hal tersebut diduga merupakan tempat yang baik ditemukannya beranekaragam mikroalga. Keanekaragaman jenis mikroalga di daerah Subak Jatiluwih belum ada yang meneliti sehingga perlu dilakukan penelitian tersebut untuk mendapatkan jenis-jenis mikroalga. Jenis padi yang diusahakan oleh petani disana yaitu padi local Cicih Merah dan padi inhibrida Ciherang. Padi Cicih Merah 
SAWIDYA FITRIYANI. et al. Genus Alga pada Lahan Sawah Organik yang Ditanami Padi...

merupakan jenis padi lokal yang berumur genjah kurang lebih masa panen 5 bulan. Tinggi padi >1-2 m,malai panjang. Karakteristik umur padi Ciherang umur panen 116-125 hari setelah tanam, anakan $>20$ tunas, dan bermalai agak lebat $( \pm 150$ butir gabah/malai), tinggi rata-rata 91-106 cm (bbpadi.litbang.pertanian.go.id). Padi Cicih Merah merupakan jenis padi lokal yang berumur genjah kurang lebih masa panen 5 bulan. Tinggi padi >1-2 $\mathrm{m}$, malai panjang. Perbedaan karakteristik morfologi dari kedua jenis padi dapat menjadi pengaruh perbedaan genus alga yang teridentifikasi. Berdasarkan data penelitian Sari (2011) pada lahan pertanian organik genus alga yang ditemukan ada empat belas genus, Niswati (2008) ditemukan dua genus alga dominan pada lahan pertanian organik sawah gambut, Erdiana (2010) ditemukan 14 genus alga pada persawahan lahan gambut. Penelitian ini bertujuan untuk mengetahui jumlah dan macam genus alga yang ditemukan pada lahan sawah organik, dengan pengambilan sampel tanah dan air sawah.

\section{BAHAN DAN METODE}

Penelitian dilaksanakan pada bulan September sampai dengan April 2018, terhitung sejak tahap awal pelaksanaan sampai tahap akhir penelitian. Tempat penelitian adalah Subak Jatiluwih, Tabanan (untuk lokasi pengambilan sampel) dan pengamatan alga dilakukan di Laboratorium Ilmu Tanah dan Lingkungan Fakultas Pertanian Universitas Udayana.

Bahan dan alat yang akan digunakan pada penelitian ini meliputi; sampel tanah, air sawah, kertas label, alat tulis, botol plastik, kaleng susu sebagai ring sampel, spite, kantong plastik, media bristol, autoclave, laminar flow, mikroskop stereo, kamera, kaca objek, cover glass, mikro pipet, tabung reaksi. Metode penelitian yang digunakan adalah deskriptif kuantitatif eksploratif. Pengukuran yang dilakukan menghitung populasi alga tanah dengan metode MPN (Alef dan Paolo, 1995). Pengambilan sampel tanah dan air dilakukan sejak penggenangan/Olah Tanah sampai dengan umur 112 hari setelah tanam. Sampel diambil secara berkala selama pertanaman padi, yaitu Olah Tanah (OT), 0, 7, 14, 21, 28 hst dan seterusnya selang waktu 2 minggu, berpatokan pada waktu pemupukan. Pengayaan sampel tanah diinokulasikan pada 9 tabung reaksi yang mana setiap 3 tabung dibiakkan alga dengan pengenceran berbeda yaitu $10^{-1}, 10^{-2}$ dan $10^{-3}$. Sampel air maupun sampel tanah kemudian, diamati dengan dituangkan ke kaca objek untuk diamati mikroalga. Pengamatan dan penghitungan 
organisme yang teramati dipisahkan dengan bantuan pipet yang diamati dibawah mikroskop stereo dengan perbesaran 50400x. Data yang diperoleh kemudian ditabulasi dan dianalisis kuantitatif deskriptif. Statistik deskriptif berfungsi untuk mendeskripsikan obyek yang diteliti melalui data sampel atau populasi (Sugiyono, 2013). Hasil dari deskriptif digunakan untuk menentukan nama-nama genus.

\section{HASIL DAN PEMBAHASAN}

Berdasarkan hasil analisis total genus yang ditemukan sebanyak 37 genus. Genus tersebut berasal dari 3 divisi yaitu, Chlorophyta (alga hijau), Cyanophyta (alga biru) dan Chrysophyta (alga keemasan/alga pirang). Ditemukan 27 genus dari sampel tanah Ankistrodesmus, Volvox, Elakatothrix, Tetrastrum, Monostroma, Desmidium, Cosmarium, Ulotrix, Stigeoclonium, Coeleastrum, Pleurococcus, Scenedesmus, Anabaena, Arthrospira, Synedra, Navicula, Mougeotia, Gloeocapsa, Chamaesiphon, Chroococcus, Pleurocapsa, Microcoleus, Nostoc, Microcystis, Melosira, Chloroclostei, Dinobyon. Sampel air hanya 12 genus yang dapat teridentifikasi yaitu; Cocconeis, Triceratium, Dinobryon, Amphipleura, Pinnularia, Gyrosigma, Craticula, Diploneis, Synedra, Tetraedron, Oedogonium, Cerasteria.

Tabel 1. Hasil Identifikasi Alga di Lokasi Penelitian

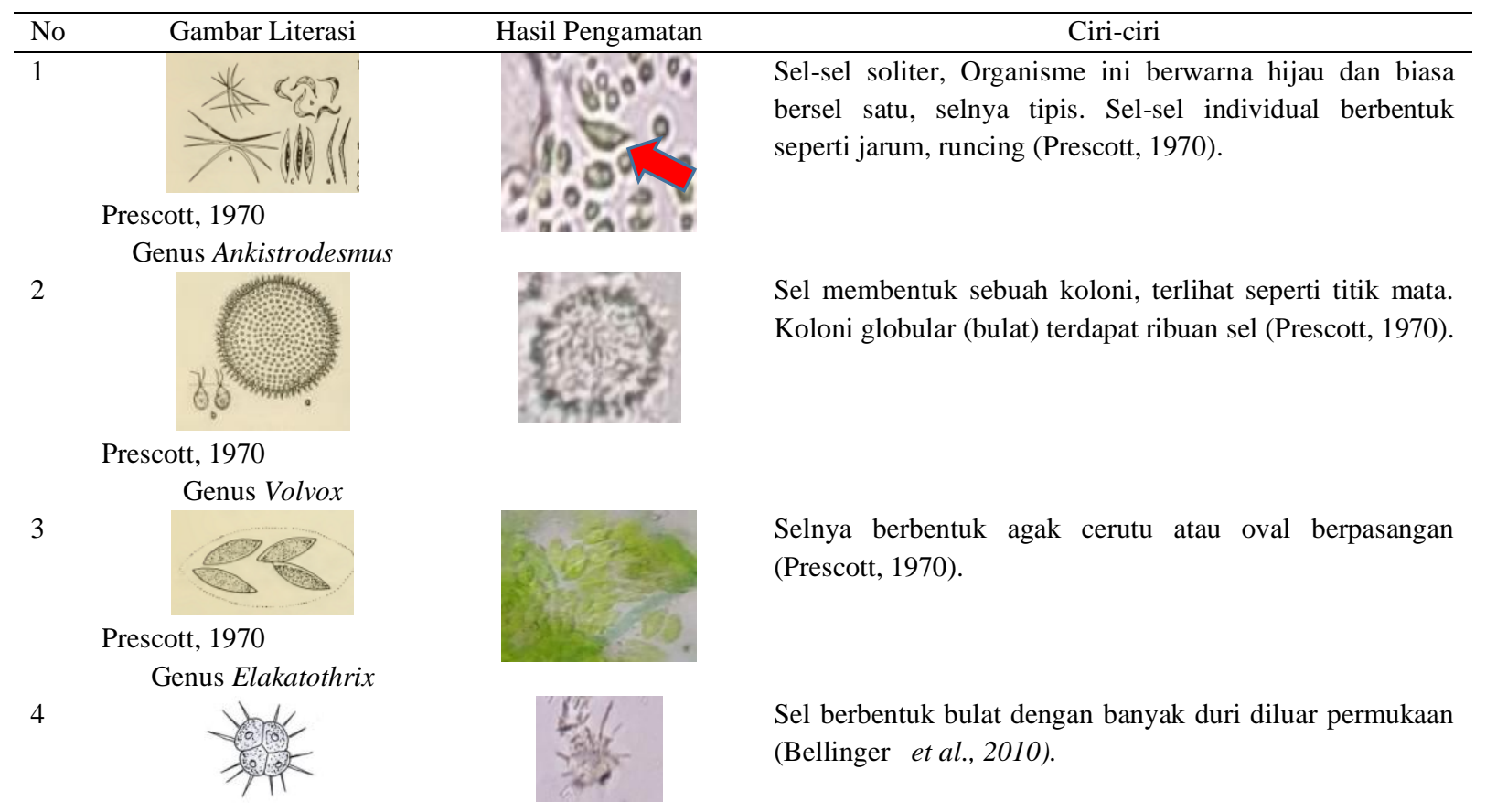


SAWIDYA FITRIYANI. et al. Genus Alga pada Lahan Sawah Organik yang Ditanami Padi...

Bellinger et al., 2010

Genus Tetrastrum

5

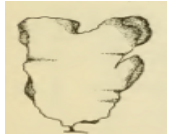

Prescott, 1970

6

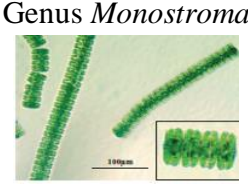

Bellinger et al., 2010

Genus Desmidium

7

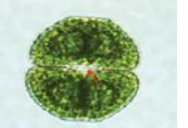

Bellinger et al., 2010

Genus Cosmarium

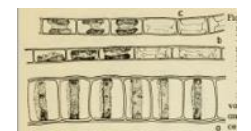

Prescott, 1970

\section{Genus Ulothrix}

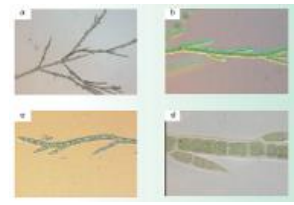

Van Vuuren, 2006

Genus Stigeoclonium

10

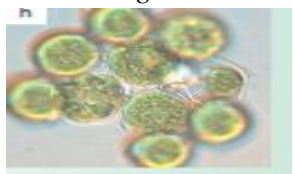

Van Vuuren, 2006

Genus Coelastrum

11

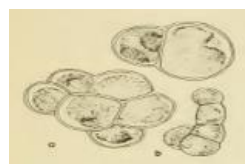

Prescott, 1970

Genus Pleurococcus

12
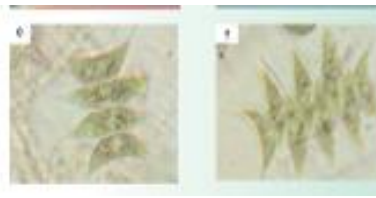

Van Vuuren, 2006

Genus Scenedesmus
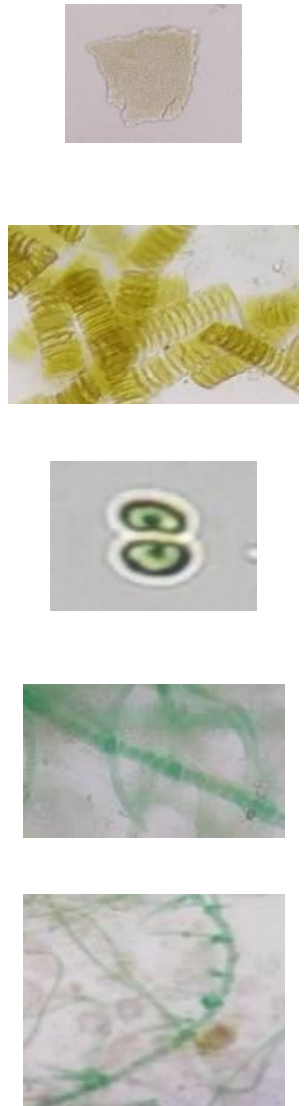

Filamen me-nempel, Filamen dikelilingi oleh lapisan mussilago tipis (Van Vuuren, 2006). Stigeoclonium sering digunakan sebagai indikator tercemarnya perairan dan bersifat toleran terhadap polusi logam berat (Van Vuuren, 2006).

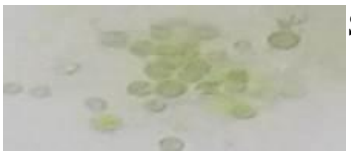

Sel tersusun koloni bentuk bulat (Van Vuuren, 2006).

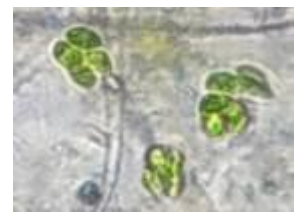

Sel berbentuk bulat biasanya dalam massa padat (Prescott, 1970).

Sel-sel silinder bentuk oval memanjang berdampingan (Van Vuuren, 2006). Scenedesmus adalah produsen primer dan sumber makanan penting untuk tingkat trofik yang lebih tinggi. Scenedesmus adalah bio-indikator umum dari perubahan fisik dan kimia dalam kondisi lingkungan, biasanya digunakan untuk mendeteksi kehadiran nutrisi atau racun yang dihasilkan dari input antropogenik sistem perairan (Van Vuuren, 2006). 
13

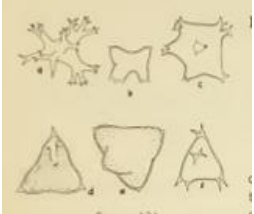

Prescott, 1970

Genus Tetraedron

14

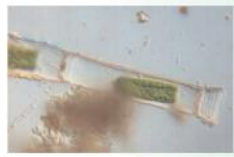

Van Vuuren, 2006

Genus Oedogonium

15

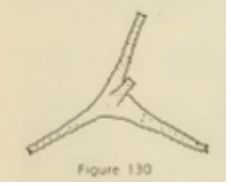

Prescott, 1970

Genus Cerasterias

16

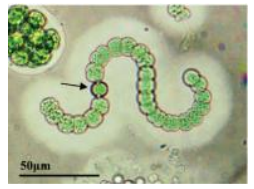

Bellinger et al., 2010

Genus Anabaena

17

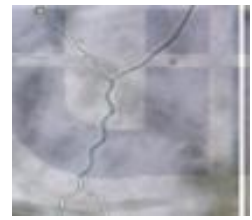

Sari, 2011

Genus Arthrospira

18

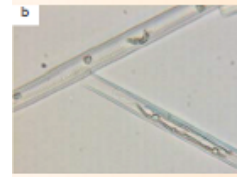

Van Vuuren, 2006

Genus Synedra

19

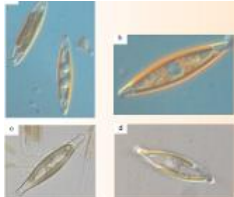

Van Vuuren, 2006

Genus Navicula

20

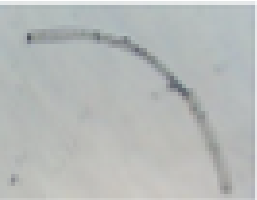

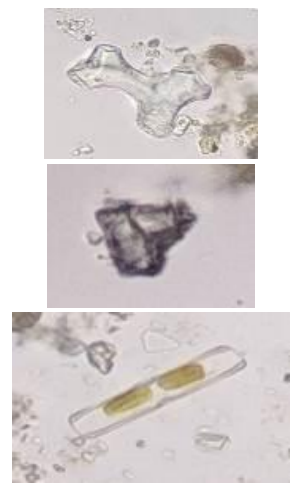

Sel bersifat soliter, ada yang berbentuk segitiga dan ada yang memiliki empat sisi (Prescott, 1970).

Sel berwarna hijau pucat tak bercabang (Van Vuuren, 2006).

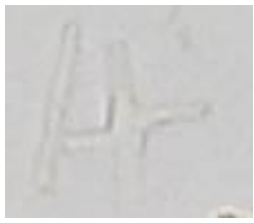

Sel secara bertahap menyempit di sudut untuk membentuk seperti tanduk (Prescott, 1970).

Sel-selnya bulat, warna koloni hijau-biru (Bellinger et al., 2010). Anabaena dapat memfiksasi N, dari udara, karena adanya sel akinet yang terbentuk saat defisiensi N (Sari, 2011).

Berbentuk filamen spiral, warna koloni tidak jelas (Sari, 2011)

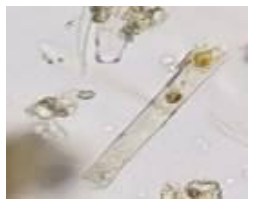

Sel soliter berbentuk batang (Van Vuuren, 2006). Synedra dapat mentolerir berbagai macam kondisi air, termasuk eutropi dan pengayaan organik. (Van Vuuren, 2006).

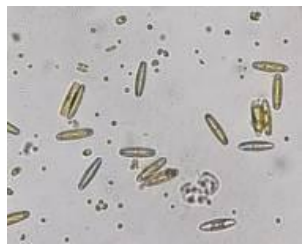

Ciri bentuk sel silinder seperti katup, konoli berwarna hjau pucat (Van Vuuren, 2006)

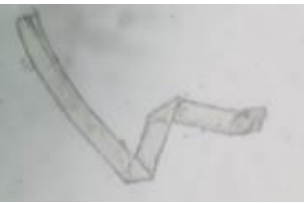

Ciri selnya panjang berbentuk silindrik (Lukitasari, 2015). 
SAWIDYA FITRIYANI. et al. Genus Alga pada Lahan Sawah Organik yang Ditanami Padi...

Lukitasari, 2015

Genus Mougeotia

21

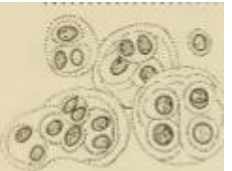

Prescott, 1970

Genus Gloeocapsa

22

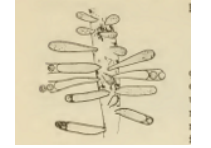

Prescott, 1970

Genus Chamaesiphon

23

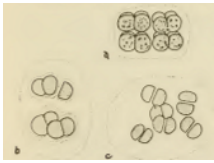

Prescott, 1970

Genus Chroococcus

24

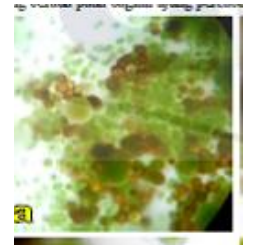

Sari, 2011

Genus Pleurocapsa

25

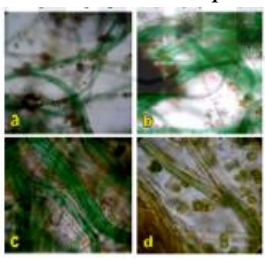

Sari, 2011

Genus Microcoleus

26

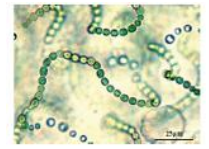

Bellinger et al., 2010

27

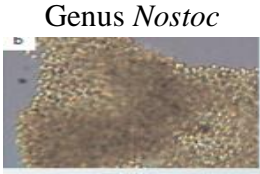

Van Vuuren, 2006

Genus Microcystis

28

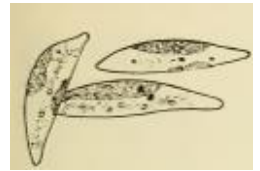

Prescott, 1970

Genus Chloroclostei

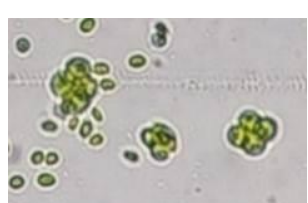

Ciri-ciri warna koloni hijau, bentuk koloni tidak beraturan (Prescott, 1970).

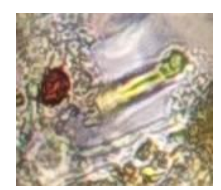

Sel menempel pada substrat lain, bentuk sel agak memanjang dengan bagian pangkal yang agak menyempit dan ujung sel bulat (Prescott, 1970).

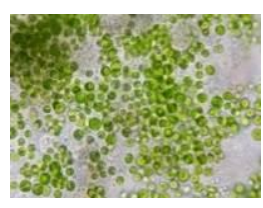

Warna sel hijau, bentuk sel tidak teratur, soliter maupun berkoloni (Prescott, 1970)

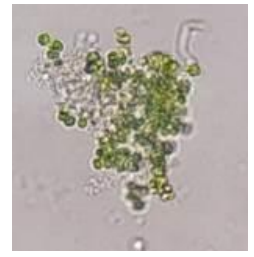

sel bentuk baris yang tidak teratur, sel tampak berupa butiran berwarna hijau dan kekuningan (Sari, 2011).

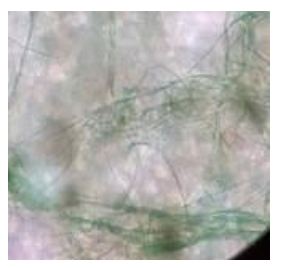

Bentuk lurus, silindris, tak bercabang, warna koloni hijaubiru (Sari, 2011).

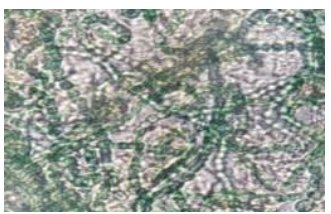

Koloni warna koloni hijau-biru atau kelabu, bentuk mengular (Bellinger et al., 2010). Nostoc digunakan untuk bahan makanan di China yang dikenal dengan nama "yuyucho". Nostoc memiliki kandungan protein yang tinggi (Sharma, 1992).

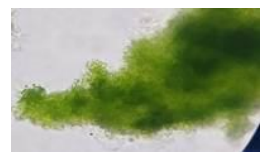

Koloni terdiri dari ribuan sel individu yang sangat kecil bentuk bola (Van Vuuren, 2006)

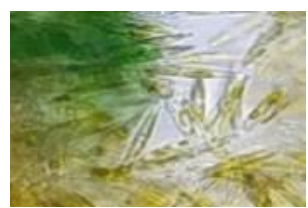

Berbentuk sabit, warna kekuningan (Prescott, 1970). 
29

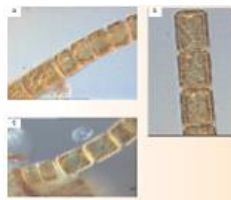

Van Vuuren, 2006

Genus Melosira

30

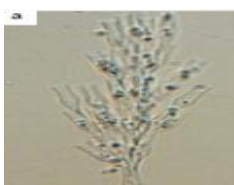

Van Vuuren, 2006

Genus Dinobryon

31

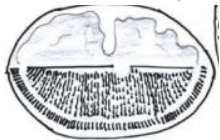

Bellinger et al., 2010

Genus Cocconeis

32

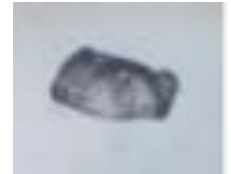

Lukitasari, 2015

Genus Triceratium

33
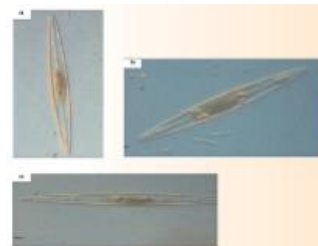

Van Vuuren, 2006

Genus Amphipleura

35

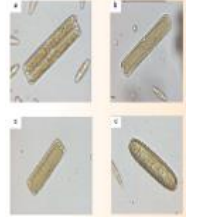

Van Vuuren, 2006

Genus Pinnularia

36

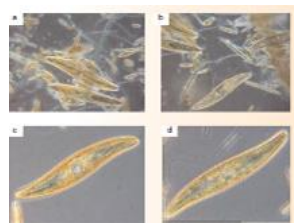

Van Vuuren, 2006

Genus Gyrosigma

37

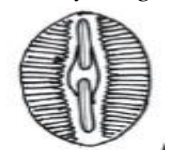

Bellinger et al., 2010

Genus Diploneis

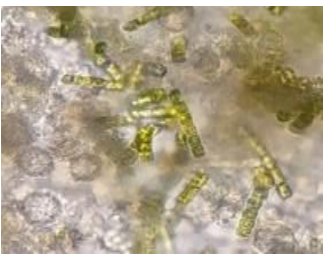

Ciri sel silinder, berwarna coklat keemasan (Van Vuuren, 2006).

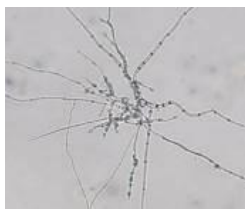

Sel memanjang melekat, dan bercabang (Van Vuuren, 2006). Adanya alga ini dalam jumlah besar dapa memberikan rasa atau bau amis yang berbahaya pada air minum (Van Vuuren, 2006).

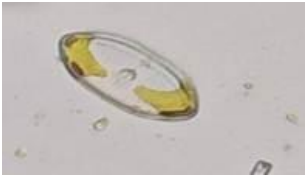

Berbentuk elips, lurik pada permukaan (Bellinger et al., 2010).

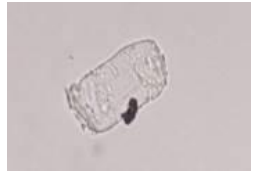

Berbentuk persegi (Lukitasari, 2015)

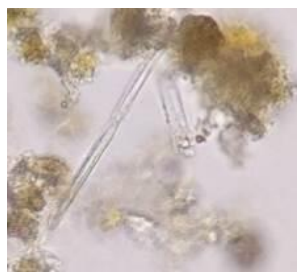

ciri raphe (garis hubung kedua sudut) pendek dengan dinding sel tebal (Van Vuuren, 2006).

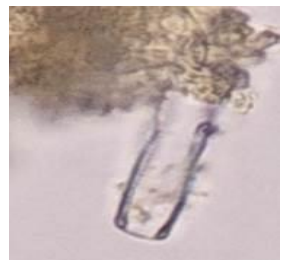

ciri sel berbentuk lanset (Van Vuuren, 2006).

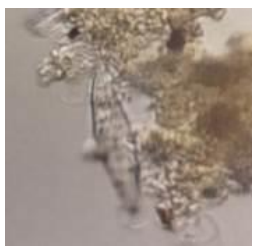

Raphe nya berbentuk S, melintang (Van Vuuren, 2006).

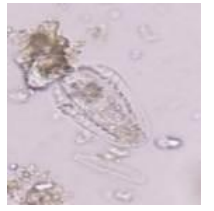

Ciri sel dengan ujung bulat, terlihat seperti gigi (Bellinger et al., 2010). 
SAWIDYA FITRIYANI. et al. Genus Alga pada Lahan Sawah Organik yang Ditanami Padi...

Alga yang ditemukan di lahan padi lokal pada fase pertumbuhan (14-25 hst) yaitu, Desmidium (Chlorophyta), Navicula (Chrysophyta) dan Microcystis (Cyanophyta). Awal fase tumbuh padi genus yang berasal dari ketiga devisi dapat teridentifikasi, hal ini menunjukkan penyerapan cahaya matahari setiap mikroalga masih terpenuhi, karena tanaman belum terlalu tinggi. Alga dominan fase vegetatif (26-65 hst) yaitu, Navicula (Chrysophyta), Gleocapsa dan Microcoleus (Cyanophyta). Fase selanjutnya genus dari divisi Chlorophyta tidak teridentifikasi, kemungkinan adanya faktor pembatas berupa cahaya pada alga hijau ini. Menurut Levasseur (1984) kelas Chlorophyceae memiliki kandungan pigmen klorofil a dan $\mathrm{b}$. Kandungan klorofil tersebut menyebabkan kelas Chlorophyceae lebih membutuhkan cahaya untuk proses fotosintesis dibandingkan kelas lainnya. Pada fase berbunga (66-85 hst), alga yang ditemukan yaitu Desmidium, Mougeotia (Chlorophyta), Synedra, Melosira (Chrysophyta), Gloeocapsa, Microcoleus (Cyanophyta). Fase generatif ditemukan genus dari ketiga divisi, disimpulkan mikroalga mampu beradaptasi dengan lingkungan. Fase pengisian biji (86-100 hst) ditemukan alga
Desmidium (Chlorophyta) dan Microcoleus (Cyanophyta) dilihat dari fase tumbuh padi, fase pengisian biji kanopi daun tinggi dan padi telah bermalai lebat. Kondisi tersebut menjadi pembatas bagi banyak mikroalga, namun tidak dengan alga Desmidium dan Microcoleus hal ini membuktikan dapat bertahan pada kondisi lingkungan terbatas baik faktor cahaya maupun unsur hara. Unsur hara Nitrogen dan Phospor sering menjadi faktor pembatas pertumbuhan mikroalga (Vance dan Griffith, 1993).

Alga dominan yang ditemukan pada lahan padi inhibrida Fase vegetatif (35 hst) ditemukan Anabaena (Cyanophyta). Teridentifikasinya alga ini menunjukkan bahwa lahan tersebut subur, hal ini dikarenakan genus ini dapat memfiksasi hara N. Anabaena salah satu agen yang sangat penting dalam memfiksasi nitrogen dan meningkatkan jumlah nutrisi tanah untuk pertumbuhan tanaman padi. Keberadaan genus ini pada setiap titik sampel menunjukkan tingginya tingkat kesuburan pada tanah persawahan (Sari, 2011). Fase generatif reproduktif (36-70 hst) alga yang teridentifikasi yaitu, Tetrastrum, Desmidium, Ulotrix, Mougeotia, (Chlorophyta), Synedra, Navicula (Chrysophyta), Chroococcus, Microcoleus, Arthrospira (Cyanophyta). 
Pada fase generatif, genus dari ketiga divisi dapat teridentifikasi, hal ini menunjukkan mikroalga mampu beradaptasi dengan lingkungan. Fase generatif pematangan (71100) alga yang dominan teridentifikasi Monostroma (Chlorophyta). Genus ini merupakan salah satu genus yang mampu bertahan pada kondisi lingkungan kritis pasalnya divisi Chlorophyta memerlukan banyak cahaya matahari untuk mendukung pertumbuhannya, sedangkan pada fase ini kanopi padi dapat menutup sebagian besar permukaan tanah sehingga cahaya matahari yang dapat sampai ketanah juga sedikit.

Alga yang ditemukan pada air permukaan lahan padi lokal fase pertumbuhan (14-25 hst) yaitu, Cocconeis dan Pinnularia (Chrysophyta). Fase vegetatif (26-65 hst) alga yang sering muncul yaitu, Dinobryon, Pinnularia dan Synedra (Chrysophyta). Pada fase berbunga (66-85 hst), alga yang ditemukan yaitu Dinobryon (Chrysophyta). Sepanjang fase tumbuh padi yang mana diambil sampel air permukaan sawah. Genus mikroalga yang mendominasi yaitu berasal dari divisi Chrysophyta, genus tersebut mudah beradaptasi dengan lingkungan. Menurut Sari dkk., (2013) genus alga dari kelas Bacillariophyceae (Chrysophyta) memiliki distribusi sangat luas meliputi air laut, air tawar dan tanah-tanah yang lembab. Bacillariophyceae memiliki kemampuan bereproduksi tinggi dibandingkan mikroalga lainnya. Umur selanjutnya tidak ditemukan air permukaan sawah pada lahan padi lokal, hal ini dikarenakan kondisi cuaca dan fase generatif telah dilakukan pemutusan air.

Alga yang ditemukan pada air permukaan lahan padi inhibrida fase vegetatif (35 hst) adalah Cocconeis, Synedra (Chrysophyta). Kondisi yang sama juga terjadi di lahan padi inhibrida dimana alga yang teridentifikasi dominan adalah genus dari kelas Bacillariophyceae (Chrysophyta). Hal ini menandakan tidak terpengaruh faktor pembatas seperti cahaya dan unsur hara khususnya pada air permukaan. Sampel air hanya tersedia sampai fase vegetatif padi inhibrida, hal ini dipengaruhi faktor cuaca. Pada umur 45 hst air irigasi padi inhibrida diputus karena telah masuk fase generative reproduktif.

Genus alga yang dapat teridentifikasi hanya sekali sepanjang umur menandakan genus tersebut sulit untuk beradaptasi. Rendahnya nilai kelimpahan mikroalga tersebut diduga karena faktor lingkungan yang kurang sesuai dengan kehidupan mikroorganisme yang bersangkutan. Jumlah kelimpahan mikroalga yang berbeda disebabkan oleh daya adaptasi yang tidak 
SAWIDYA FITRIYANI. et al. Genus Alga pada Lahan Sawah Organik yang Ditanami Padi...

sama dari semua genus yang ditemukan. populasi tertinggi $>1.100 \mathrm{sel}^{-1}$ tanah, Lingkungan yang mengalami perubahan sedangkan populasi terendah hanya pada menyebabkan jenis mikroalga tertentu kisaran angka 3,6 sel g-1 tanah. Populasi alga jumlahnya akan meningkat, sementara yang hanya diperoleh pada sampel tanah, lain akan mengalami penurunan.

Metode MPN digunakan untuk pengayaan laboratorium.

menghitung populasi alga yang telah diperkaya. Berdasarkan Tabel 2 diketahui

Tabel 2. Populasi Alga Pengayaan Tanah Tabel MPN 3 Seri Tabung (Blodgett, 2006)

\begin{tabular}{|c|c|c|c|c|c|c|c|c|c|}
\hline \multirow{3}{*}{$\begin{array}{l}\text { Umur } \\
\text { Padi }\end{array}$} & \multirow{2}{*}{\multicolumn{3}{|c|}{$\begin{array}{l}\text { Lahan Padi Lokal } \\
\text { Tabung Positif }\end{array}$}} & \multirow{3}{*}{ Sel $\mathrm{g}^{-1}$} & \multirow{3}{*}{$\begin{array}{l}\text { Umur } \\
\text { Padi }\end{array}$} & \multirow{2}{*}{\multicolumn{3}{|c|}{$\begin{array}{c}\text { Lahan Padi Inhibrida } \\
\text { Tabung Positif }\end{array}$}} & \multirow{3}{*}{ Sel $g^{-1}$} \\
\hline & & & & & & & & & \\
\hline & 0,1 & 0,01 & 0,001 & & & 0,1 & 0,01 & 0,001 & \\
\hline $\mathrm{OT}$ & 3 & 2 & 1 & 150 & OT & 3 & 3 & 3 & $>1.100$ \\
\hline 0 & 3 & 2 & 1 & 150 & 0 & 3 & 3 & 1 & 460 \\
\hline 7 & 3 & 3 & 2 & 1.100 & 7 & 3 & 3 & 3 & $>1.100$ \\
\hline 14 & 1 & 0 & 0 & 3,6 & 14 & 3 & 2 & 3 & 290 \\
\hline 21 & 3 & 3 & 0 & 240 & 21 & 3 & 3 & 3 & $>1.100$ \\
\hline 28 & 3 & 3 & 1 & 460 & 28 & 3 & 3 & 2 & 1100 \\
\hline 42 & 1 & 1 & 1 & 11 & 42 & 2 & 1 & 2 & 27 \\
\hline 56 & 2 & 2 & 1 & 28 & 56 & 3 & 3 & 3 & $>1100$ \\
\hline 70 & 3 & 2 & 3 & 290 & 70 & 2 & 1 & 1 & 20 \\
\hline 84 & 3 & 3 & 2 & 1.100 & 84 & 2 & 1 & 1 & 20 \\
\hline 98 & 1 & 1 & 0 & 7,4 & 98 & 2 & 0 & 0 & 9,2 \\
\hline 112 & 2 & 1 & 2 & 27 & 112 & 1 & 2 & 1 & 15 \\
\hline
\end{tabular}

Hubungan total populasi dengan yang dapat dihitung dengan metode MPN jumlah genus alga yaitu, kemelimpahan jenis juga bervariasi tergantung dari medium yang dan jumlah alga pada kondisi tertentu. digunakan untuk pertumbuhan (Sari, 2008). Metode MPN digunakan untuk menghitung Apabila total populasi tinggi saat ditemukan jumlah jasad renik di dalam contoh yang jenis alga juga banyak, maka kemelimpahan berbentuk cair, meskipun dapat pula jumlah dan genus pada kondisi tersebut digunakan untuk contoh berbentuk padat banyak. Berbeda jika total populasi tinggi dengan terlebih dahulu membuat suspensi namun genus alga yang ditemukan sedikit, 1:10 dari contoh tersebut. Grup jasad renik maka kemelimpahan hanya pada jumlah alga. 
Apabila, genus yang ditemukan banyak sedang total populasi rendah, kemelimpahan hanya pada genus alga. Apabila total populasi sedikit dan genus yang ditemukan sedikit juga, maka tidak terjadi kemelimpahan pada kondisi tersebut. Kelimpahan jumlah dan genus alga pada lahan padi lokal terjadi pada $7 \mathrm{hst}$, dengan total genus yang ditemukan 13 dan total populasi 1.100 sel $\mathrm{g}^{-1}$ tanah. Lahan padi inhibrida kelimpahan jumlah dan genus alga terjadi pada 7 dan 21 hst dengan total sama genus yang ditemukan 18 dan total populasi $>1.100 \mathrm{sel} \mathrm{g}^{-1}$ tanah. Perbedaan jumlah genus dari kedua lahan disebabkan oleh faktor cahaya yang sampai pada permukaan sawah, karena batang padi Cicih lebih tinggi dari padi Inhibrida maka cahaya matahari semakin sedikit yang sampai kepermukaan sawah.

\section{SIMPULAN}

Ditemukan sebanyak 37 genus yang berasal dari sampel tanah dan air, yang mana termasuk dalam 3 divisi yaitu, Chlorophyta (alga hijau), Cyanophyta (alga biru) dan Chrysophyta (alga keemasan/alga pirang). Ditemukan 27 genus pada sampel tanah. Genus dominan pada lahan padi lokal yaitu: Desmidium presentase kehadiran 91,7\%, Navicula dan Microcoleus presentase kehadiran 75\%, sedangkan genus yang kemunculannya terendah yaitu: Ulotrix dan Stigeoclonium dengan presentase kehadiran 8,3 $\%$. Ditemukan lebih banyak genus dominan pada lahan padi inhibrida yaitu: Microcoleus presentase kehadiran 75\%, Desmidium, Arthrospira, Navicula dan Chroococcus presentase kehadiran 66,7\%, sedangkan genus yang kemunculannya terendah Elakatothrix, Chamaesiphon dan Pleurocapsa dengan presentasi kehadiran $8,3 \%$. Total populasi alga tertinggi pada lahan padi lokal saat padi berumur 7 dan 84 hst yaitu sebanyak 1100 sel g $^{-1}$ tanah, sedangkan total terendah yaitu 3,6 sel $\mathrm{g}^{-1}$ tanah pada saat padi berumur 14 hst. Total populasi tertinggi alga lahan padi inhibrida pada saat padi berumur OT, 7, 21 dan 56 hst yaitu sebanyak >1100sel $\mathrm{g}^{-1}$ tanah, sedangkan total populasi terendah yaitu 9,2 sel $\mathrm{g}^{-1}$ tanah pada umur 98 hst.

\section{DAFTAR PUSTAKA}

Alef, K dan Paolo, N. 1995. Methods In Applied Soil Microbiology and Biochemistry. San Diego: Academic Press

Bellinger E.G, and David C. S., 2010. Freshwater Algae: Identification and Use as Bioindicators. John Wiley and Sons, Ltd.

Blodgett, R. Appendix. 2006. Most Probable Number from Serial Dilution. BAM (Bacteriological Analytical Manual), Chapter 4. FDA (Food and Drug 
SAWIDYA FITRIYANI. et al. Genus Alga pada Lahan Sawah Organik yang Ditanami Padi...

Administration). U.S. Department of Health \& Human Services.

Erdiana, L. 2010. Keanekaragaman dan Kelimpahan Alga Mikroskopis pada Daerah Persawahan di Desa Sungai Lumbah Kecamatan Alalak Kabupaten Barito Kuala. Jurnal: Wahana-Bio. http://bbpadi.litbang.pertanian.go.id/in dex.php/varietas/inbrida-padi-sawahirigasi-inpari/content/item/1-ciherang.

Levasseur, M. J. C., and Legendre, L., 1984. Hierarchial Control of Phytoplankton Succession by Physical Factors. Journal: Mars, Ecol. Prog. Ser.

Niswati, A. 2008. Perubahan Populasi Protozoa dan Alga Dominan pada Air Genangan Tanah Padi Sawah yang Diberi Bokashi Berkelanjutan. Lampung: J. Tanah Trop., Vol. 13, No. 3, 2008: 225-231 ISSN 0852-257X.

Prescott, G.W. (1970). The Freshwater Algae. University of Montana. WM.C. Brown Company Publishers. Dubuque, Lowa.

Sari, N. K. 2008. Pemanfaatan Biosolid. Klaten: Yayasan Humaniora.

Sari, W.E. 2011. Isolasi Dan Identifikasi Mikroalga Cyanophyta dari Tanah Persawahan Kampung Sampora, Cibinong, Bogor. Jakarta: UIN Syarif Hidayatullah

Sari, R.M., Sri Ngabekti, F. Putut Martin H. B. 2013. Keanekaragaman Fitoplankton di Aliran Sumber Air P Condrodimuko Gendongsongo Kabupaten Semarang. Jurnal: Unnes Journal of Life Science.
Sugiyono. 2013. Metode Penelitian Kuantitatif, Kualitatif dan R\&D. Bandung: Alfabeta. CV

Vance,C.P. and Griffith,S.M.1993. The Molecular Biology of N Metabolism in Plant Physiology, Biochemistry and Molecular Biology. Edited by Dennis, D.T. and Turpin,D.H. Longman Scientific and Technical. England.

Van Vuuren, et al. 2006. Easy Identification of The Most Common Freshwater Algae. Afrika Selatan: North-West University and Department of Water Affairs and Forestry. 